\title{
What Are The Antecedents to Creating Sustainable Corporate Entrepreneurship in Thailand?
}

\author{
Laddawan Lekmat \\ University of the Thai Chamber of Commerce \\ E-Mail: laddawan_lek@utcc.ac.th \\ John Chelliah \\ University of Technology \\ E-Mail: john.chelliah@uts.edu.au
}

\begin{abstract}
Corporate entrepreneurship (CE) is broadly seen as an essential tool for competitiveness, particularly in today's fast-paced and complex global economy. However, there is a lack of research on the CE strategies of Asian companies in response to the Asian financial and the global financial crisis in developing Asian countries. In this study, the model of CE antecedents and effects is examined for 287 Thai managers at various levels within the targeted firms' operating in a wide variety of industries. Specifically, the impact of internal environment factors on CE and the relationship between $\mathrm{CE}$ and diverse firm performance aspects is mediated by process innovation. Results indicate that only three of the five antecedents to CE have primary effects on $\mathrm{CE}$ as well as process innovation. $\mathrm{CE}$ has a significant indirect effect on company performance through the mediation of process innovation. Process innovation is found to be a predictor of innovation performance and a predictor of marketing performance, which in turn affects financial outcomes. The implications of these results for both $\mathrm{CE}$ theory and practice are discussed. As there is a dearth of empirical research in this area, this paper makes a useful contribution by highlighting the CE initiatives of Thai companies to survive any future crises and the stiff competition present in the Asian region.
\end{abstract}

Keywords: Corporate entrepreneurship (CE), process innovation, firm performance, Corporate Entrepreneurship Assessment Instrument, structural equation modeling. 


\section{INTRODUCTION}

Organizations are continually under competitive pressures and forced to exploit new opportunities, develop and launch new products, services, markets and technologies (Tajeddini, 2010) and place innovation at the core of their firm's competitive advantage (Morris et al., 2008).

Corporate entrepreneurship (CE) is a potential survival strategy for firms operating in highly competitive business environments. $\mathrm{CE}$ is viewed as the pursuit of entrepreneurial actions and initiatives that transform the existing organization through strategic renewal processes and/or extending the firm's scope of operations into new domains, that is, product-market or technological innovation (Goodale et al., 2011). Therefore, companies must seriously consider CE strategy as a means for their organizations to achieve both long-term survival and growth (Martin-Rojas et al., 2013; Tajeddini, 2010; Burns 2008).

To be an entrepreneurial firm, entrepreneurial endeavors must be integrated into a firm's overall strategies (Goodale et al, 2011; Tajeddini, 2010) and steered by a strong entrepreneurial mindset that stimulates engagement in innovative or entrepreneurial behavior (Duobiene and Pundziene, 2007). There is a general lack of consensus on the precise key internal factors that stimulate sustainable entrepreneurial behavior (Hornsby et al., 2013; Tahseen, 2012). Many studies view innovation as the core of entrepreneurship, particularly product-market innovation (Goodale et al, 2011; Morris et al, 2008). Other studies have focused on either entrepreneurship or innovation as an independent process, resulting in limitations in their application and usefulness (McFadzean et al, 2005). While research (e.g. Kickul et al, 2011) on entrepreneurship has developed substantially over the recent decades, the intersections between operations management and entrepreneurship remain scarce. Kickul et al. (2011) suggest that cross-disciplinary research and its practice is a fruitful approach that not only leads to new insights but also can produce tangible benefits for firms. In addition, certain empirical studies focus primarily on a few measured outcomes of CE with a bias directed toward positive financial results (Haar and White, 2013). However, theseCE studies often ignore the micro-level effects of entrepreneurial orientation (EO) and activities on an organization's sustained financial performance and thus have failed to broaden the full understanding of CE and its precise impact on business performance overall and for the future.

This study contributes knowledge related to "how" entrepreneurial a firm is and determines the underlying reasons "why" sustainable entrepreneurial behavior is actually being achieved, and also how entrepreneurial activities contribute to corporate performance in the Thai context. The study, explores the antecedents and 
effects of entrepreneurial activity in Thai firms for various industries by focusing on various aspects of firm performance, such as innovation performance, market performance, and financial performance. The study then offers recommendations for established firms that are interested in developing their entrepreneurial capability and behavior further as an effective path to sustaining their long-term development.

\section{THEORETICAL BACKGROUND AND HYPOTHESES}

\section{Corporate Entrepreneurship (CE)}

A number of researchers have recognized the importance of entrepreneurial behavior as an organization-level phenomenon (Alegre and Chiva, 2013; Lekmat and Chelliah, 2011; Real et al, 2012; Tajeddini, 2010). Brizek and Khan (2007) indeed argue that the context of firm-level entrepreneurship should be delineated to generate consistency in both methodology and findings. In analyzing the diverse and complex definition of entrepreneurship, the pursuit of opportunity becomes the essence of entrepreneurship. CE is, therefore, viewed as an organizational process, and it includes both opportunity identification and an action component (Bratnicki 2005).

Management research has highlighted that EO influences "how entrepreneurship is put into practice" (Alegre and Chiva, 2013, p. 491). EO is described as firm level entrepreneurship (Todorovic and Ma, 2008) and relates to management practices regarding decision-making styles and processes that support managers' entrepreneurial behavior (Real et al, 2012). EO can thus be an important measure of how entrepreneurial a firm actually is (Morris et al, 2008; Real et al, 2012; Tahseen, 2012).

In this study, a firm's entrepreneurship is defined as the process of creating value and wealth by which managers in an established organization pursue entrepreneurial opportunities, innovation, and self-renewal, all of which require an EO managerial attitude. The EO construct that includes innovativeness, risk- taking, and proactiveness is widely used in many studies (e.g. Alegre and Chiva, 2013; Hornsby et al, 2013; Javalgi and Todd, 2011; Tang and Hull, 2012; Tang and Tang, 2012; Todorovic and $\mathrm{Ma}, 2008)$. Innovativeness refers to creativity support, new product and service introduction, and new process development (Javalgi and Todd, 2011). Risk taking involves management willingness to obligate significant resources to seek out opportunities (Nasution et al, 2011) that have both a chance of failure and the opportunity for success (Ireland et al, 2006). Proactiveness is concerned with opportunity seeking and exploitation of resources that can be the source of innovation, competitive advantage, and first-mover benefits in the marketplace (Ireland et al, 2006). 


\section{The Internal Environment and Corporate Entrepreneurship (CE)}

The Corporate Entrepreneurship Assessment Instrument (CEAI) developed by Hornsby et al (2002) has been widely accepted and employed by researchers to measure organizational antecedents for implementing a CE strategy (Hornsby et al, 2013; Ireland et al, 2006). Hornsby et al (2013, p. 938) suggest that the "CEAI instrument is a critical tool to advance research in the area of organizational antecedents to $\mathrm{CE}$ and provide insight into the important consideration of proentrepreneurship organizational architecture".

According to Hornsby et al (2002), the five factors that are precursors of managers' entrepreneurial management style are: (1) Top management support, which relates to the inclination of top-level managers to facilitate and stimulate entrepreneurial actions throughout an organization (Sebora et al, 2010); (2) Work discretion/autonomy, which involves top-level managers' commitment to tolerate failure, delegate authority and provide middle- and lower-level managers with the freedom to make decisions about their work in theways they believe are most effective (Kuratko et al, 2013); (3) Rewards/reinforcement involves developing and using organizational systems that reward based on performance and also support entrepreneurial activity (Kuratko et al, 2013); (4) Time availability involves estimating workloads to guarantee that individuals have the time needed to develop new ideas and innovations and supporting their efforts to accomplish short- and longterm corporate goals (Ireland et al, 2006); (5) Organizational boundaries refer to a barrier-free organization based on the value of management stimulus to strive for coordination (Sebora et al, 2010) and resource sharing to assess, select and utilize innovations (Kuratko et al, 2013).

These factors, individually and in combination, are theoretically considered for supporting entrepreneurial initiatives within an existing organization (Hornsby et al., 2013). Investigating the influence of these factors individually on EO should provide better understanding of the $\mathrm{CE}$ drivers and how well firms sustain their own entrepreneurial-oriented actions. Ireland et al. (2009) suggest that appropriate structures and processes are required for CE to work effectively (Burgess, 2013). Therefore, the CEAI is a useful tool for assessing and managing a firm's internal environment and thus to facilitate entrepreneurial behavior that becomes the foundation for successfully implementing a CE strategy (Ireland et al., 2006)

Previous research ((Hornsby et al, 2013; Goodale et al., 2011; Sebora et al., 2010; Holt et al., 2007) supports the concept that CEAI is positively associated with a firm's EO. Further, the research points out that this relationship may be reciprocal, in which case, EO in turn leads to a more entrepreneurially supportive organizational 
environment. Future research could provide a broader understanding of the complexity of the actual interconnection between organizational readiness and orientation (Hornsby et al., 2013). It should be noted, however, that although, CEAI has been shown to be psychometrically sound and a viable means for exploring the precursors of entrepreneurial-oriented behavior, the investigation of the linkages between CEAI and entrepreneurial opportunity recognition and exploitation have been limited (Sebora et al, 2010; Brizek and Khan, 2007; Hornsby et al., 2002). Measuring an organization's internal environment has, however, been posited and confirmed as an important path for successfully implementing a CE strategy (Hornsby et al., 2013; Ireland et al., 2006). Tahseen (2012) suggests that entrepreneurial firms undertake product-market novelty, carry out somewhat risky ventures, and are the first to introduce proactive innovation. This process is accomplished by providing the right organizational climate and the appropriate conditions for both innovation and entrepreneurship to occur.

This study proposes that the internal environment, including top management support, work discretion/autonomy, rewards/reinforcement and time availability, and organizational boundaries are the predictors of EO, and in that regard, the following hypothesis is put forward:

Hypothesis 1: Internal environment will positively relate to CE.

H1a: Management support will positively relate to EO

$H 1 b$ : Work discretion/autonomy will positively relate to EO

H1c: Rewards/reinforcement will positively relate to EO

H1d: Time availability will positively relate to EO

H1e: Organizational boundaries will positively relate to EO

\section{Corporate Entrepreneurship (CE), Process Innovation and Firm Performance}

The phenomenon of EO as a prerequisite for innovation has become a central focus of the CE literature. The term "innovation" is not only mentioned in relation to creation and the application of a new product and process, but it is also linked to marketing and organization (Gunday et al, 2011). Process innovation is a focus of this study and refers to a new element introduced into an organization's production or service operations, such as input materials, task specifications, work and information flow mechanisms, and equipment actually used to produce a product or render a service(Nasution et al., 2011) as well as used to generate ideas, and recognize and exploit new opportunities(Laforet, 2010). Process innovation leads to changes in both production and delivery methods (Gunday et al, 2011) as well as improvement in management practices and processes (Nasution et al, 2011). Process innovation also 
includes quality functions and business process re-engineering (Nasution et al, 2011) and provides different methods for improving quality, reducing costs, and producing or delivering new value-added products (Gunday et al, 2011). Research shows that EO in terms of innovation, risk taking and proactiveness represents an important organizational process that does lead to successful process innovation results (Nasution et al., 2011; Tajeddini, 2010; Tahseen, 2012). However, the relationship between EO and process innovation requires further analysis (Alegre and Chiva, 2013) since process innovation is considered the main consequence of entrepreneurial actions. Therefore, the EO of a firm is likely to influence actual process innovation. The following hypothesis is thus put forward:

Hypothesis 2: EO positively relates to process innovation.

$\mathrm{CE}$ is viewed as a critical organizational process that helps a firm to survive and grow in uncertain environment conditions (Tajeddini et al, 2010). Haar and White (2013) indicate that a firm with a higher level of entrepreneurship can achieve a higher profitability, growth, and competitive advantage than its competitors. Although, there is a large body of research that demonstrates a positive association between EO and a firm's financial performance (e.g. Moreno and Casillas, 2008; Real et al, 2012; Sebora et al, 2010; Tang and Tang, 2012; Todorovic and Ma, 2008), some of these findings have not been fully conclusive (Alegre and Chiva, 2013). Real et al (2012) suggest that the contributions of EO to performance need a broader exploration of the intermediate variables that exist between EO and organizational outcomes.

Further still, the discussion of the impact of EO on non-financial outcomes is limited in the literature (Todorovic and Ma, 2008). Todorovic and Ma (2008,) stress that the influences of CE $\mathrm{n}$ non-financial outcomes need to be further explored, as these may be as important as actual financial outcomes. Lekmat and Chelliah (2011) in their research provide evidence that the impacts of entrepreneurial activity are related to the non-financial criteria of corporate performance in the early years of an entrepreneurial project, including increased customer satisfaction, process improvement, or product quality, and these aspects will improve superior financial results later. Thus, financial and non-financial criteria can be useful when evaluating the performance of firm-level entrepreneurship at different points in time (Carton and Hofer, 2006). Organizations that are engaging in entrepreneurial activities are expected to achieve a higher level of financial outcomes and also positive nonfinancial aspects than organizations that are lower in entrepreneurship engagement.

This study proposes that the indirect effects of entrepreneurial activities can be expected to lead to innovation and market performance through the actual mediation 
of process innovation. In this respect, process innovation plays the role of an affective hub that produces a positive impact on entrepreneurial activities. Laforet (2010) suggests that the positive end results of process innovation are improved efficiency, an easy way of working, cost benefits, and process simplification. These improvements and achievements are seen as actual sources of profitability since productivity can improve business outcomes and maximize profit margins (Laforet, 2010; OECD, 2005; Tajeddini, 2010). Therefore, process innovation not only results in a a positive consideration of higher innovativeness, but also an improved market position and financial returns that then result in increased competitive advantage and superior performance of the firm (Gunday et al, 2011). Process innovation can actually increase a firm's performance in three different performance dimensions, namely, innovation, market, and financial(Alegre and Chiva, 2013; Gunday et al., 2011; Goodale et al., 2011; Tahseen, 2012; Tajeddini, 2010; Tang and Tang, 2012). Therefore, process innovation is likely to influence firm performance in both financial and non-financial aspects. The following hypothesis is thus put forth:

Hypothesis 3: The positive relationship between EO and firm performance is mediated by process innovation.

H3a: Process innovation positively relates to market performance

$H 3 b$ : Process innovation positively relates to innovation performance

H3c: Process innovation positively relates to financial performance

\section{METHODOLOGY}

\section{Data Collection and Procedure}

The survey questionnaire was originally developed in English and then translated into Thai by a professional translator and then translated back into English by another professional translator. The questionnaire was pretested with six CEOs of Thai companies ( they were not included in the final sample) to ensure the integrity of the translation and also improve the understanding of the questions (Lekmat and Chelliah, 2011). Data were collected from managers at several levels within the targeted firm using questionnaire-based surveys to match the nature of the inquiry with the relevant source of information and overcome common method variance in the survey response. A survey team distributed the questionnaires to each participating firm in Bangkok and its metropolitan area. Of the 400 survey packages distributed, 287 were returned. Hence 287 usable questionnaires were obtained producing a response rate of $71.75 \%$. Applying Tajeddini (2010, p. 224), to achieve this high "response rate, different strategies were used, such as making more contacts, altering the length and the form of [the]survey, a personalized cover letter, as well as a 
promise of feedback and confidentiality". The respondents were also contacted by phone to explain the objective and the significance of the study before permission was sought to collect the actual survey data.

\section{Measurement}

To assess the organizational antecedents of $C E$, this study adopted the Corporate Entrepreneurship Assessment Instrument (CEAI) developed by Kuratko et al. (1990) which was further refined by Hornsby et al. (2002). The 48-item CEAI included five dimensions: Top management support, work discretion/autonomy, rewards/reinforcement, time availability, and organization boundaries. The respondents were asked to indicate a supportive entrepreneurial environment in their organizations using a 5-point Likert-type scale $(1=$ 'strongly disagree' to $5=$ 'strongly agree').

The entrepreneurship orientation scale was adopted from Ireland et al (2006). Respondents were asked to identify the entrepreneurial activities and orientations within their organization and then asked to indicate on a 5-point Likert-type scale $(1=$ 'strongly disagree' to $5=$ 'strongly agree') 12 items that measured entrepreneurship in terms of innovativeness, risk taking, and proactiveness. The respondents were then asked to indicate on another 5-point Likert-type scale $(1=$ 'significantly less' to 7 = 'significantly more') 11 items that measured process innovation, which enables innovation to be an inherent part of their organization's operations. All items were developed by Gunday et al (2011) and Nasution et al. (2011).

Firm performance was measured on a 16-item scale adopted by Goodale et al (2011) and Gunday et al (2011). The subjective data referred to managers' perceptions of the multiple dimensions of organizational performance compared to their main industry competitors over the past three years. To account for any lagged effect, measurement items for these variables were the actual reported measures for the previous three years. The respondents were asked to rate the variables on a five-point Likert-type scale $(1=$ 'very dissatisfied' to $5=$ 'very satisfied'). This Likert-type instrument consisted of 2 items measuring financial performance, 3 items measuring market performance, and 11 items measuring innovation performance. These scales further addressed both financial and non-financial aspects, providing a holistic conceptualization of firm performance (Lekmat and Chelliah, 2011).

\section{Controls}

Firm size and firm age were included as control variables. Company size was indicated by the number of full-time employees (up to 250: small to medium; and 
above 250: large). According to Gunday et al (2011), company age was measured by the number of years a firm has been in operation (before 1975: old; between 1975 and 1992: moderate; 1992 and later: young).

The data were also controlled via the t-test procedure for non-response bias and no significant difference $(p<0.05)$ that was found in the data set responses either in entrepreneurial activity and firm performance variables or in terms of control variables. In the analyses, variables such as firm size and firm age, were examined as control variables, since these organizational variables may have an influence on both entrepreneurial activity and firm performance.

As the study collected information from groups of respondents from the same companies, multiple-rater reliability was investigated. The Interclass Correlation Method examines inter-rater agreement (Boyer and Verma, 2000). Within-group variance and between-group variance were compared and an $F$ statistic was generated. All $F$ statistics were significant $(p<0.05)$ for all items in this current study. Thus, all items reflected good multiple-rater reliability.

Data collected from managers at different levels within a targeted firm can overcome the issue of common method variance (CMV) in the survey responses. However, the respondents were asked to self-report their responses, so the issue of CMV was examined. Harmon's Single Factor Test was utilized to address this issue. All factors of antecedents to CE variables and performance in a study were analyzed separately, using exploratory factor analysis (EFA) and any unrotated factor solution was also examined (Podsakoff et al, 2003). Factor analysis resulted in 5 factors of antecedents to $\mathrm{CE}$ with eigenvalues greater than 1.0, which accounted for $27.67 \%$ of the total variance; with factor 1 accounting for $9.96 \%$ of the variance. Similarly, factor analysis resulted in 3 factors of performance with eigenvalues greater than 1.0, which accounted for $55.56 \%$ of the total variance; with factor 1 accounting for $8.89 \%$ of the variance. Without a single factor emerging from the unrotated factor solution or one factor that explained the majority of the covariance, common method effects were probably not significant within the data in this study.

\section{ANALYSIS AND RESULTS}

\section{Respondent and Organizational Profiles}

Table 1 provides information on the demographic and organizational characteristics of the respondents. The total number of respondents were 287 with male being $52.1 \%$ and female, $47.9 \%$. The respondents were from top management $(40.6 \%)$ or middle management $(59.4 \%)$. There were more large companies $(59.9 \%)$ than small-sized and medium-sized enterprises or SMEs (40.1\%). The cases were split 
according to the number of full-time employees: Cases below 250 employees were classified as SMEs and above 250 employees were classified as large. Firm age was determined by the year when production started and thereby classified as young $(49.1 \%)$ and moderate to old $(50.9 \%)$. The firms surveyed were distributed among the sectors as follows: Textile (3.1\%), chemical (4.5\%), metal products $(2.7 \%)$, machinery $(7.0 \%)$, personal care products $(5.9 \%)$, electronics $(6.3 \%)$, paper products (5.6\%), national gas and refined fuels $(8.4 \%)$, food and agriculture products $(8.0 \%)$, automotive industries $(11.8 \%)$, real estate $(5.2 \%)$, computers and telecommunications (5.6\%), hotel (4.3\%), furniture (4.2\%), and financial service (17.4\%).

\section{Measurement Reliability and Validation}

Since all measures were adopted from Western culture- based studies, this study is exploratory research with an aim of testing the specified hypotheses to determine the applicability of Western-based existing theories in a Thai context. This will provide insights into what are drivers of $\mathrm{CE}$ and how Thai firms can support them. Prior to testing the CE antecedents and performance model, an exploratory factor analysis (EFA) was conducted to uncover key dimensions of the entrepreneurial activities, CE antecedents, process innovation, and performance. The approach adopted sought to achieve the best representation of the latent factors while reducing the number of observed indicators to a manageable level for robust estimates. A principal components factor analysis (PCA) with varimax rotation was utilized. Only items with factor loadings of 0.45 or above were selected for any particular factor (Tajeddini, 2010). Items that loaded significantly on more than one factor were dropped. With respect to these requirements, convergent validity was also ensured. The factor loadings were all significant at $p<0.001$ and ranged from a low of 0.45 to a high of 0.89 , which supported convergent validity. Then, the reliability of each construct was evaluated by Cronbach's alpha. Reliability estimates for entrepreneurship (0.74), process innovation (0.92), management support (0.86), work discretion/autonomy (0.85), rewards/reinforcement (0.84), time availability (0.68), organizational boundary (0.68), innovation performance (0.94), market performance (0.83), and financial performance (0.87) revealed a moderate to high level of internal consistency. 
Table 1: Demographic Characteristics of Respondents $(\mathrm{n}=287)$

\begin{tabular}{|c|c|}
\hline Description & $\%$ \\
\hline \multicolumn{2}{|l|}{ Gender of respondents } \\
\hline Male & 52.1 \\
\hline Female & 47.9 \\
\hline \multicolumn{2}{|l|}{ Ages of respondents } \\
\hline 35 years or less & 46.3 \\
\hline $36-45$ years & 36.8 \\
\hline $46-55$ years & 14.4 \\
\hline over 56 years & 2.5 \\
\hline \multicolumn{2}{|l|}{ Position of respondents } \\
\hline Top manager & 40.6 \\
\hline Middle-level manager & 59.1 \\
\hline \multicolumn{2}{|c|}{ Length in years of respondents' tenure in current firm } \\
\hline$<5$ years & 49.1 \\
\hline $6-10$ years & 26.5 \\
\hline $11-15$ years & 10.6 \\
\hline $16-20$ years & 8.5 \\
\hline Above 20 years & 5.3 \\
\hline \multicolumn{2}{|c|}{ Length in years of respondents' tenure in current industry } \\
\hline$<5$ years & 38.7 \\
\hline $6-10$ years & 28.9 \\
\hline $11-15$ years & 12.7 \\
\hline $16-20$ years & 11.3 \\
\hline Above 20 years & 8.5 \\
\hline \multicolumn{2}{|l|}{ Firm size } \\
\hline Medium companies (less than 250 ) & 40.1 \\
\hline Large companies (over 250) & 59.9 \\
\hline \multicolumn{2}{|l|}{ Industry Classification of firms } \\
\hline textile & 3.1 \\
\hline chemical & 4.5 \\
\hline metal products & 2.7 \\
\hline machinery & 7.0 \\
\hline personal care products & 5.9 \\
\hline electronics & 6.3 \\
\hline paper products & 5.6 \\
\hline national gas and refined fuels & 8.4 \\
\hline food and agriculture products & 8.0 \\
\hline automotive industry & 11.8 \\
\hline property development & 5.2 \\
\hline computers and telecommunications equipment & 5.6 \\
\hline furniture & 4.2 \\
\hline hotel & 4.3 \\
\hline financial service & 17.4 \\
\hline
\end{tabular}


To assess discriminant validity between all the constructs, an average variance extracted (AVE) test was conducted. If the AVE is higher than 0.05, discriminant validity between all constructs is assured (Tajeddini, 2010). The results in this case indicated that the AVE scores of all constructs, with exception reward/reinforcement, were higher than 0.50 , signifying discriminant validity between the constructs. Although, the AVE values for the reward/reinforcement constructs were lower than 0.05 , these constructs have been widely recognized, so this study retained this construct as its district construct (Kuratko et al, 2013). Overall, all measures generally revealed acceptable psychometric properties (Nasution et al, 2011).

Table 2 reports the results of the analysis of the relationships among the study variables. As indicated in the correlation analysis, all components of five antecedent conditions to EO, with the exception of time availability, significantly related to one another, thus supporting results/findings in previous research that revealed that these factors are indicators of entrepreneurial activities (Kuratko et al, 2013). In this study, only time availability was perceived as not linked to entrepreneurial activity in firms. Among the respondents in this study, entrepreneurship activities significantly related to firm performance in terms of market, innovation, and financial performance. This result supported the previous research, that is, firm-level entrepreneurship leads to higher firm performance (Alegre and Chiva, 2013; Gunday et al, 2011; Todorovic and Ma, 2008; Real et al, 2012).

\section{Hypotheses Testing}

Structural Equation Modeling (SEM) was used to test the hypotheses as it combines factor analysis and multiple regression in one procedure (Hair et al, 2006). Therefore, SEM was an appropriate statistic tool for this study for data analysis because it examines a series of interdependent relationships simultaneously. Moreover, SEM provides a conceptually appealing way to test theory and assesses how well that theory fits reality as represented by the collected data (Kline, 2005). In this study, the model was found not to fit the data well, $\chi^{2}(57)=258.14, p=0.00$, $\mathrm{CMIN} / \mathrm{DF}=4.53, \mathrm{RMSEA}=0.11, \mathrm{GFI}=0.88$ and $\mathrm{CFI}=0.90$. The $\chi 2$ value and GFI were less satisfactory in terms of fit. An inspection of the modification indices based on theory justification suggested that removing insignificant paths and adding structural paths from 'market performance' to 'innovative performance' and 'market performance' to 'financial performance' could improve the model, $\chi 2(51)=97.52, p$ $=0.00, \mathrm{CMIN} / \mathrm{DF}=1.91, \mathrm{RMSEA}=0.06, \mathrm{GFI}=0.95$ and $\mathrm{CFI}=0.97$. Thus, the adjusted model shown in Figure 1 was considered preferable. 


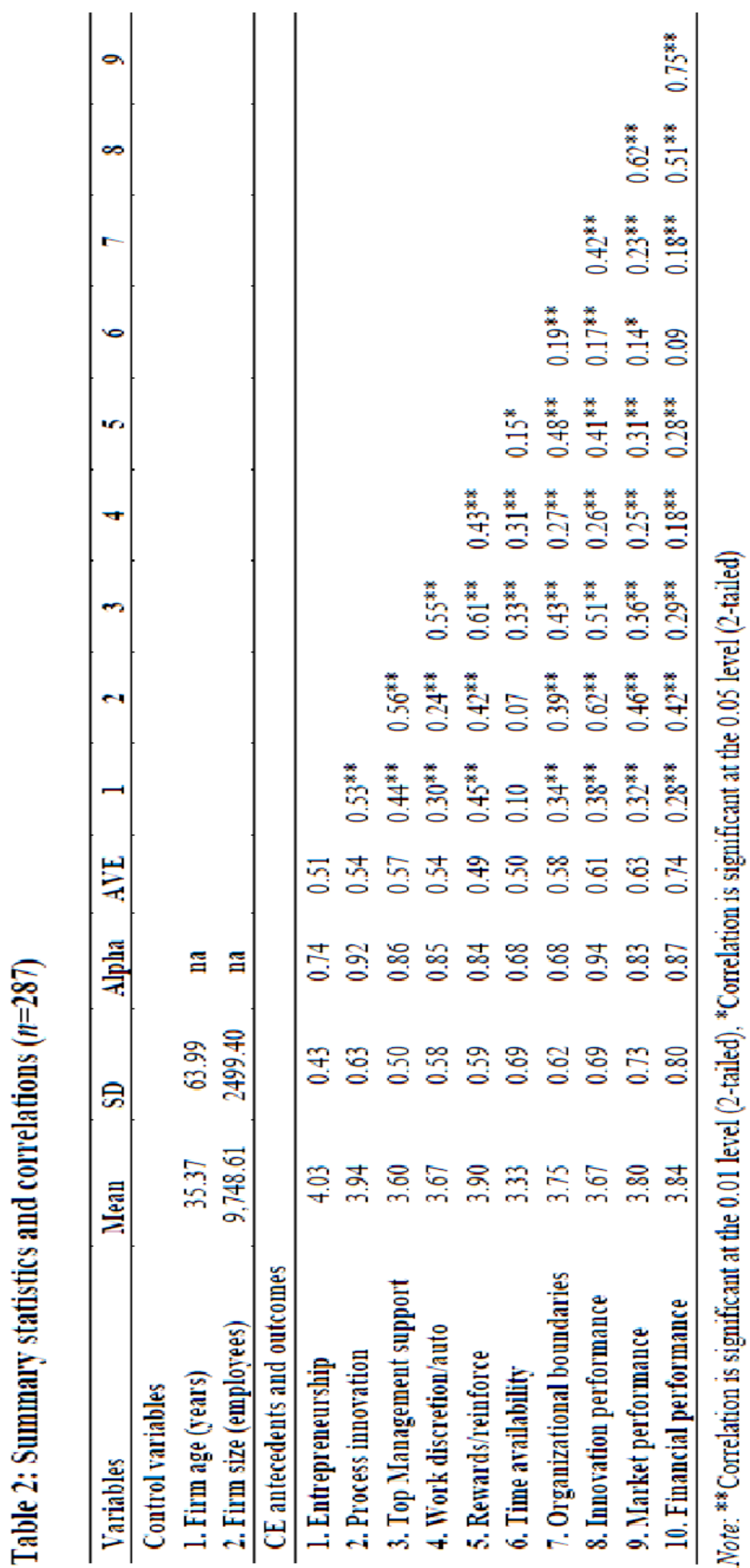




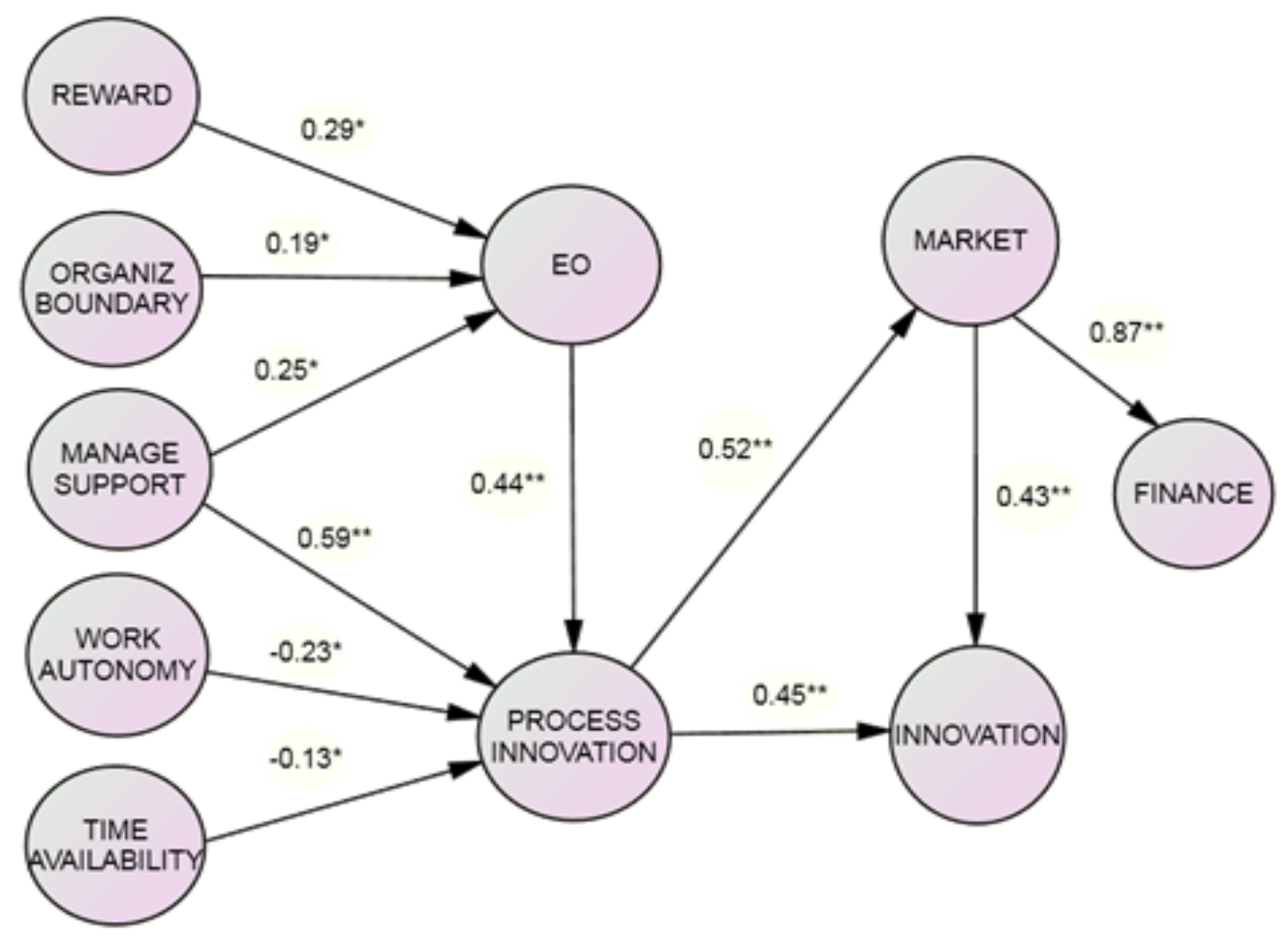

Note: **significant at $p<0.01, *$ significant at $p>0.05$

Figure 1 Final model of $\mathrm{CE}$ antecedents and performance

All arrows in Figure 1, which indicate the supported association, are significant $(p<0.05)$. Three of the five antecedents to CE were significantly predictive of EO (innovativeness, risk taking and proactiveness). Management support, rewards/reinforcement and organizational boundaries respectively positively related to EO (H1a, H1c, and H1e supported). There was no support in the data for the hypotheses that suggested that work discretion/autonomy (H1b not supported) or time availability (H1d not supported) affects EO. The regression estimates in the SEM model indicated that rewards/reinforcement and top management support are the strongest drivers of EO, furthersuggesting that they are very influential in promoting entrepreneurial activities. Top managers need to set the tone for innovation and need to encourage their employees to believe that innovation is part of a role that is set for all employees in the company (Greenberg and Baron, 2008; Tahseen, 2012). Moreover, managers (?) need to be willing to facilitate entrepreneurial projects by providing resources, such as human and financial resources, that will make innovation possible (Sebora et al, 2010). In terms of rewards/reinforcement, the study findings 
suggest that entrepreneurship would be impossible to implement if there were no motivation (Kuratko et al, 2013). Thus, employees behave entrepreneurially when the appropriate incentives are introduced to elicit and reinforce entrepreneurial behavior. Further, appropriate rewards enable innovations to occur both faster and better (Sebora et al, 2010). The interesting finding beyond the hypothesized model indicated that three of the five antecedents to $\mathrm{CE}$ are also significantly predictive of process innovation. Top management support has both direct and positive effects on process innovation, whereas work discretion/autonomy and time availability have direct and also negative impacts on process innovation. These results indicate that entrepreneurial activities are inhibited when managers have limited autonomy, work overload, and time constraints. Organizations in which managers have highly structured work are likely to be slow in implementing ideas (Goodale et al, 2011; Sebora et al, 2010; Morris et al, 2008). Goodale et al (2011) found that the presence of control-related structures, policies, systems, and operating management philosophies in an organization seem to be a restriction to the freedoms needed to successfully promote entrepreneurial behavior.

With regard to the effect of EO on process innovation, EO was found to be positively associated with process innovation ( $\mathrm{H} 2$ supported). These findings show that EO has an indirect positive impact on market and innovation performance via process innovation. In addition, process innovation was found to be positively associated with marketing (H3a supported) and have both direct and indirect (through marketing performance) effects on innovation performances (H3b supported). However, process innovation was not found to be positively related to financial performance ( $\mathrm{H} 3 \mathrm{c}$ not supported). These findings show that process innovation has an indirect effect (through marketing performance) on financial performance. Marketing competence is viewed as one of the basics for financial outcomes since customer satisfaction, market share, and sales growth can make significant contributions to financial goals achieved with improved product quality and delivery (Gunday et al, 2011; Lekmat and Chelliah, 2011; Tahseen, 2010).

The preferred model confirms that internal environments for $\mathrm{CE}$ are likely to support entrepreneurial behavior and the use of CE strategy. Also, this model verifies that EO stimulates process innovation, which in turn sustains innovation performance and market performance, thereby improving financial performance overall.

\section{CONCLUSION AND IMPLICATIONS}

This study reported on entrepreneurial activities in Thailand's manufacturing and service industries. A theoretical framework was empirically investigated, specifying 
the antecedents to the creation of sustainable entrepreneurship and the indirect effects of $\mathrm{CE}$ on firm performance through the process innovation mediation. The study not only discloses how $\mathrm{CE}$ affects various firm performance facets; it also indicates that process innovation does act as a mediator role between $\mathrm{CE}$ and performance criteria.

Internal climate variables were examined to aid in the understanding of the development of sustainable entrepreneurial behavior in firms. The findings of this study back the claim that internal climate variables support innovation, entrepreneurial behavior, and the use of CE strategy. Management support is the most significant predictor of both entrepreneurial behavior and process innovation, suggesting that top management is critical in formulating and implementing entrepreneurship in a company as an ongoing way of thinking and acting (behavior). Needless to say, top management is the key to stimulating employees to think and act entrepreneurially. Thus, the internal working environment should be the focus of ongoing design and development efforts by management.

In addition, the relationships between $\mathrm{CE}$ and the various aspects of corporate performance (market, innovation and financial performance) were found to have significant positive correlations. The path model analysis indicated that market performance and innovation performance are outcomes of $\mathrm{CE}$ via process innovation, suggesting that $\mathrm{CE}$ tends to increase company performance. However, the positive relationship between $\mathrm{CE}$ and performance is mediated by process innovation. Although the direct association between process innovation and financial performance was not found to be significant in this instance, the impact of process innovation on financial outcomes is mediated by market performance. Therefore, a focus on the impact of $\mathrm{CE}$ on multidimensional performance measures based on both financial and non-financial aspects will broaden the conceptualization of performance as well as contribute to a better understanding of CE-performance relationship implications. Importantly, the results suggest that process innovation tends to play the most important role because it acts as mediator wherein CE is likely to sustain market, innovation and financial performance.

In 1997, Thailand was among the countries worst affected by the Asian financial crisis. Consequently, growth, particularly growth via innovation, was viewed as the key priority for long-term survival and prosperity for Thai companies, as competition from China and neighboring ASEAN countries increased substantially. CE is viewed globally as a key driver of sustainable growth and competitive advantage in companies and the economic development in nations. It is therefore crucial that Thai companies recognize and understand forces that drive CE. 
The findings of this study offer several managerial implications. First, to improve company performance, entrepreneurial behavior should be encouraged by creating an entrepreneurial climate using internal environment factors. People at all levels of a company can play critical roles in successful entrepreneurship efforts, so the actions of top management become especially critical and must fulfill particular roles in the entrepreneurial process. They must invest in the development of people. The other lesson learned from entrepreneurial firms is that priorities must be turned upside down - that firms must invest in their employees first and understand that value creation for customers then follows and recognize that productive employees and satisfied customers will create more wealth for stockholders. Moreover, this study supports the fact that the entrepreneurial behavior of a firm is an important major driver of process innovation, which in turn improves organizational performance. Firms that possess the resources to develop their innovative competencies and improvement processes can expect a more substantial enhancement of their innovation and market outcomes when they have encouraged and implemented entrepreneurship activities as a fundamental part of their business strategy (Gunday et al, 2011). It was observed that increased financial performance occurs as the result of increased market performance, which depends on obtaining higher process improvement and innovation. Therefore, process innovation plays the most important function since it acts as a mediating position, where the positive effects of entrepreneurial activities are gathered and then boost innovation and market and financial results (Gunday et al, 2011).

\section{LIMITATIONS AND FUTURE RESEARCH}

The study does have some limitations. First, the study was limited to Thai firms. Interpretation should, therefore be cautious when generalizing this study to other industries and countries. Also, all data were gathered via a cross-sectional method; therefore, it is reasonable to conclude that the role variables and their results related to only a specific point in time (Tajeddini, 2010, p. 229). Finally a certain amount of time might be necessary to reflect on the positive effects of $\mathrm{CE}$ performance in Thailand specifically financial outcomes. This study measures performance over a three-year period, which thus does not capture the long-term effects of CE.

Building from the results of the study, there are certain implications for future research. First, it would be insightful to replicate this study with new and larger sample. Second, more variables could be incorporated into the model, such as other types of innovations (e.g. product and market innovations) since all individual innovation forms may be more or less positively related to certain other facets of 
organizational outcomes (Gunday et al, 2011). Positive and negative outcomes of CE and process innovation would provide more insights since CE (?) can have negative as well as positive impacts. Moreover, global and national financial crises and natural disasters do make business conditions unpredictable (Tajeddini, 2010, p. 229). Thus future research is needed to understand entrepreneurship endeavors in the context of tough times, possibly even encompassing corporate social responsibility and its dimensions. It is also necessary to include a certain amount of time to observe the long-term positive effects of process innovation on financial performance. Prior studies suggest that a longitudinal study might indeed discover the direction of the interconnection between the variables of CE study (Tajeddini, 2010).

\section{ACKNOWLEDGMENT}

This study was supported by a grant from the Research Support Office of the University of the Thai Chamber of Commerce. The author wishes to gratefully acknowledge the valuable feedback offered by anonymous reviewers.

\section{REFERENCES}

Alegre, J. \& Chiva, R. (2013). Linking entrepreneurial orientation and firm performance: The role of organizational learning capability and innovation performance. Journal of Small Business Management, 51 (4), 491-507. http://dx.doi.org/10.1111/jsbm.12005

Boyer, K.K. \& Verma, R. (2000). Multiple raters in survey-based operations management research: a review and tutorial. Production and Operations Management, 9 (2), 128-140. http://dx.doi.org/10.1111/j.19375956.2000.tb00329.x

Brizek, M. G. \& Khan, M. A. (2007). An empirical investigation of corporate entrepreneurship intensity in the casual dining sector. Hospitality Management, 26, 871-885. http://dx.doi.org/10.1016/j.ijhm.2006.07.008

Burgess, C. (2013). Factors influencing middle managers' ability to contribute to corporate entrepreneurship. International Journal of Hospitality Management, 32, 193-201.

Burns, P. (2008). Corporate entrepreneurship: building the entrepreneurial organization (2nd ed.). New York, Palgrave Macmillan.

Carton, R. B. \& Hofer, C. W. (2006). Measuring organizational performance: Metrics for entrepreneurship and strategic management research, Northampton, Edward Elgar. 
Duobiene, J. \& Pundziene, A. (2007). Development of entrepreneurial organizational culture. Economics and Management, 5(3), 507-515.

Goodale, J.C., Kuratko, D. F., Hornsby, J.S. \& Covin, J. G. (2011). Operations management and corporate entrepreneurship: the moderating effect of operations control on the antecedents of corporate entrepreneurship activity in relation to innovation performance. Journal of Operations Management, 29(1), 116-127. http://dx.doi.org/10.1016/j.jom.2010.07.005

Greenberg, J. \& Baron, R.A. (2008) Behaviour in organizations (9th ed.). Upper Saddle River, New Jersey, Pearson Prentice Hall.

Gunday, G., Ulusoy, G., Kilic, K. \& Alpkan, L. (2011). Effects of innovation types on firm performance. International Journal of Production Economics, 133, 662676. http://dx.doi.org/10.1016/j.ijpe.2011.05.014

Haar, J.M. \& White, B.J. (2013). Corporate entrepreneurship and information technology towards employee retention: A study of New Zealand firms. Human Resource Management Journal, $23 \quad$ (1), 109-125. http://dx.doi.org/10.1111/j.1748-8583.2011.00178.x

Hair, J.F, Black, W.C, Babin, B.J, Anderson, R.E. \& Tatham, R.L. (2006). Multivariate data analysis (6th ed.). New Jersey. Pearson Prentice Hall.

Holt, D. T., Rutherford, M. W. \& Clohessy, G. R. (2007). Corporate entrepreneurship: an empirical look at individual characteristics, context, and process. Journal of Leadership and Organizational Studies, $13 \quad$ (4), 40-54. http://dx.doi.org/10.1177/10717919070130040701

Hornsby, J.S., Kuratko, D.F. \& Zahra, S.A. (2002). Middle managers' perception of the internal environment for corporate entrepreneurship: assessing a measurement scale. Journal of Business Venturing, 17 (3), 253-273. http://dx.doi.org/10.1016/S0883-9026(00)00059-8

Hornsby, J. S., Kuratko, D. F., Holt, D.T. \& Wales, W.J. (2013). Assessing a measurement of organizational preparedness for corporate entrepreneurship. Journal of Product Innovation Management, 30 (5), 937-955. http://dx.doi.org/10.1111/jpim.12038

Ireland, R. D., Kuratko, D. F. \& Morris, M. H. (2006). A health audit for corporate entrepreneurship: innovation at all levels. Part II. Journal of Business Strategy, 27 (2), 21-29. http://dx.doi.org/10.1108/02756660610650019

Javalgi, R.G. \& Todd, P.R. (2011). Entrepreneurial orientation, management commitment, and human capital: The internationalization of SMEs in India. Journal of Business Research, 64, 1004-1010. http://dx.doi.org/10.1016/j.jbusres.2010.11.024 
Kickul, J.R., Griffiths, M.D., Jayaram, J. \&Wagner, S.M. (2011). Operations management, entrepreneurship, and value creation: emerging opportunities in a cross-disciplinary context. Journal of Operations Management, 29, 78-85. http://dx.doi.org/10.1016/j.jom.2010.12.004

Kline, R. B. (2005). Principles and practice of structural equation modeling. NY, The Guilford Press.

Kuratko, D.F., Montagno, R.V. \& Hornsby, J.S. (1990). Developing an intrapreneurial assessment instrument for an effective corporate entrepreneurial environment. Strategic Management Journal, 11 (1), 49-58.

Kuratko, D.F., Hornsby, J.S. \& Covin, J.G. (2013). Diagnosing a firm's internal environment for corporate entrepreneurship. Business Horizons, 57 (1), 37 47. http://dx.doi.org/10.1016/j.bushor.2013.08.009

Lekmat, L. \& Chelliah, J. (2011). Surviving the next economic crisis: corporate entrepreneurship strategies in Thai automotive SMEs. Journal of International Management Studies, 6(3), 18-35.

Laforet, S. (2010). Organizational innovation and outcomes in SMEs. Advances in Business Marketing and Purchasing, 16, 341-362.

McFadzean, E., O'Loughlin, A. \& Shaw, E. (2005). Corporate entrepreneurship and innovation part 1: the missing link. European Journal of Innovation Management, 8 (3), 350-372. http://dx.doi.org/10.1108/14601060510610207

Moreno, A.M. \& Casillas, J.C. (2008). Entrepreneurial orientation and growth of SMEs: a causal model. Entrepreneurship Theory and Practice, 32(2), 507-528. http://dx.doi.org/10.1111/j.1540-6520.2008.00238.x

Morris, M. H., Kuratko, D. F. \& Covin, J. G. (2008). Corporate entrepreneurship and innovation (2nd ed.). Mason, USA, Thomson South-Western.

Nasution, H. N., Mavondo, F. T., Matanda, M. J. \& Ndubisi, N. O. (2011). Entrepreneurship: its relationship with market orientation and learning orientation and as antecedents to innovation and customer value. Industrial Marketing Management, 40, 336-345. http://dx.doi.org/10.1016/j.indmarman.2010.08.002

OECD (2005). Oslo manual: proposed guidelines for collecting and interpreting technological innovation data. Paris.

Podsakoff, P. M., Mackenzie, S.B., Lee, J.Y. \& Podsakoff, N. P. (2003). Common method bias in behavioral research: a critical review of the literature and recommended remedies. Journal of Applied Psychology, 55 (2), 879-903. 
Real, J. C., Roldán, J. L., \& Leal, A. (2012). From entrepreneurial orientation and learning orientation to business performance: analysing the mediating role of organizational learning and the moderating effects of organizational size. British Journal of Management. http://dx.doi.org/10.1111/j.1467-8551.2012.00848.x

Martín-Rojas, R., García-Morales, V. J., \& Bolívar-Ramos, M. T. (2013). Influence of technological support, skills and competencies, and learning on corporate entrepreneurship in European technology firms. Technovation, 33(12), 417430.http://dx.doi.org/10.1016/j.technovation.2013.08.002

Sebora, T. C., Theerapatvong, T. \& Lee, S. M. (2010). Corporate entrepreneurship in the face of changing competition: a case analysis of six Thai manufacturing firms. Journal of Organizational Change and Management, 23 (4), 453-470. http://dx.doi.org/10.1108/09534811011055421

Tahseen, A.A. (2012). Entrepreneurial intensity in the corporate sector in Oman: The elusive search creativity and innovation. International Business Research, 5 (9), 171-183.

Tajeddini, K. (2010). Effect of customer orientation and entrepreneurship orientation on innovativeness: evidence from the hotel industry in Switzerland. Tourism Management, 31, 221-231.

Tang, Z. \& Tang, J. (2012). Entrepreneurial orientation and SME performance in China's changing environment: The moderating effects of strategies. Asia Pacific Journal of Management, 29, 409-431.

Tang, Z. \& Hull, C. (2012). An investigation of entrepreneurial orientation, perceived environmental hostility and strategy application among Chinese SMEs. Journal of Small Business Management, $50 \quad$ (1), 132-158. http://dx.doi.org/10.1111/j.1540-627X.2011.00347.x

Todorovic, Z.W. \& Ma, J. (2008). Entrepreneurial and market orientation relationship to performance. Journal of Enterprising Communities: People and Places in the Global Economy, 2 (1), 21-36. 
